\title{
Aging and Renal Disease: Old Questions for New Challenges
}

\author{
Yu-Hsiang Chou ${ }^{1,2}$, Yung-Ming Chen ${ }^{2,3^{*}}$ \\ ${ }^{1}$ Department of Internal Medicine, National Taiwan University Hospital Jin-Shan Branch, New Taipei City 20844, \\ Taiwan. ${ }^{2}$ Renal Division, Department of Internal Medicine, and ${ }^{3}$ Department of Geriatrics and Gerontology, \\ National Taiwan University Hospital, College of Medicine, National Taiwan University, Taiwan.
}

[Received May 21, 2020; Revised June 23, 2020; Accepted July 3, 2020]

\begin{abstract}
Chronic kidney disease (CKD) is a growing problem among aging population, and the number of individuals at risk of end stage renal disease is rising. Part of the reason lies in incomplete understanding of the pathways underlying renal aging and kidney disease, as well as insufficient delivery of evidence-based treatment to elderly patients with CKD. This review aims to address these unsolved issues by delineating updated mechanisms of renal senescence and summarizing recent findings on key clinical aspects of CKD in the elderly. Challenges and obstacles in caring for older people with CKD are discussed, with an emphasis on modification of risk factors, prevention of acute kidney injury, stabilization of progression and decision on dialysis initiation.
\end{abstract}

Key words: aging, elderly, chronic kidney disease, acute kidney injury, end stage renal disease, dialysis

Chronic kidney disease (CKD) is increasingly being recognized among the elderly population, which pose significant challenges for clinicians around the world [13]. Many elderly people are diagnosed with CKD based merely on declining estimated glomerular filtration rate (eGFR) [4], but whether this is a process of normal aging or disease development remains controversial. In this review, we will first delineate differences between renal aging and kidney disease, and describe potential pathways and mechanisms underlying renal aging. These are followed by discussion of recent findings regarding the epidemiology, risk factors, progression and outcomes of CKD in the elderly. Finally, updated recommendations about the care of older patients with CKD are provided, with an emphasis on modification of risk factors, prevention of acute kidney injury, stabilization of renal progression and decision on dialysis initiation.

\section{Renal aging versus kidney disease}

As people age, renal mass declines by about $10 \%$ per decade from aged 30 to 80 years old [5]. The number of functional nephrons also decreases, in association with a reduction of renal cortical thickness by $10 \%$ per older decade of age [6]. Renal blood flow decreases by approximately $10 \%$ per decade, along with a decline in GFR at a similar rate after age 40 [7]. Single-nephron GFR and glomerular volume, however, remain relatively constant with healthy aging [8]. Table 1 summarizes structural and functional changes of the aging kidney in the absence of overt anatomical or urinary abnormalities $[9,10]$.

*Correspondence should be addressed to: Dr. Yung-Ming Chen, Renal Division, Department of Internal Medicine, National Taiwan University, College of Medicine, No. 1, Jen-Ai Road, Section 1, Taipei 100, Taiwan, E-mail: yungmingchen@ntu.edu.tw.

Copyright: $\odot 2020$ Chou YH et al. This is an open-access article distributed under the terms of the Creative Commons Attribution License, which permits unrestricted use, distribution, and reproduction in any medium, provided the original author and source are credited. 
Table 1. Structural and functional changes of the aging kidney.

\begin{tabular}{|c|c|}
\hline Structural changes & Functional changes \\
\hline $\begin{array}{l}\text { Glomerulus } \\
\text { - Decreased number of glomeruli } \\
\text { - Increased glomerulosclerosis (focal and global, but not } \\
\text { segmental) } \\
\text { - Progressive decrease followed by increase in size of } \\
\text { glomeruli } \\
\text { - Shunts formation between afferent and efferent arterioles } \\
\text { - Thickening of glomerular basement membrane } \\
\text { - Increased mesangial volume and matrix } \\
\text { Tubule } \\
\text { - Decreased tubular number, volume, and length } \\
\text { - Tubular atrophy with simplification of tubular epithelium } \\
\text { and thickening of tubular basement membrane } \\
\text { - Increased number of tubular diverticuli } \\
\text { - Acquired cysts } \\
\text { Interstitium \& vasculature } \\
\text { - Increased interstitial volume and interstitial fibrosis } \\
\text { - Pericapsular fibrosis } \\
\text { - Arteriosclerosis }\end{array}$ & $\begin{array}{l}\text { - GFR decline } \\
\text { - Stable single nephron GFR } \\
\text { - Stable and minimal urinary albumin excretion } \\
\text { - Decreased renal blood flow } \\
\text { - Decreased sodium resorption } \\
\text { - Decreased potassium excretion } \\
\text { - Decreased urine concentrating capacity } \\
\text { - Increased renal sympathetic tone } \\
\text { - Decreased nitric oxide production } \\
\text { - Reduced hemodynamic response to vasodilating } \\
\text { stimulus }\end{array}$ \\
\hline
\end{tabular}

Studies of healthy living kidney transplant donors have provided appropriate information on both structural and functional changes that occur with normal aging. Because kidney donors undergo a sequential of clinical evaluations, including renal function and image study to confirm health before donation. Pre-implantational biopsy of the renal allograft may provide renal tissues for structural evaluation. For example, in an observational study involving 1203 adult living kidney donors, Rule et al. observed a rising prevalence of nephrosclerosis with aging, from $2.7 \%$ for ages $18-29$ years to $73 \%$ for ages 70 77 years, as determined by core needle biopsy of the graft kidney. They found a strong association between age and nephrosclerosis even after adjustment for kidney function and risk factor covariates such as diabetes and hypertension [11].

The diagnosis of CKD by eGFR $<60 \mathrm{~mL} / \mathrm{min}$ in older people has been criticizing for overestimating the CKD burden in the elderly population because eGFR generally declines inversely with aging, and reduction of eGFR to $50-59 \mathrm{~mL} / \mathrm{min} / 1.73 \mathrm{~m}^{2}$ does not increase mortality risk among patients $\geqq 65$ years compared to patients with eGFR of more than $60 \mathrm{~mL} / \mathrm{min} / 1.73 \mathrm{~m}^{2}[12$, 13]. Alternatively, a meta-analysis performed by Coresh et al. argued that even smaller decreases in eGFR could be associated with increased mortality and risk of endstage renal disease (ESRD) [14]. This raises uncertainty about using the traditional eGFR thresholds of CKD to predict outcomes for the elderly. Therefore, there is a need for a more sensitive indicator or formula to estimate kidney function in the elderly [15]. Recently, Delanaye et al. called for age-adapted definition of CKD to avoid inappropriate care. They emphasized when using eGFR definition for CKD diagnosis, CKD should be defined with respect to clinical outcomes or complications at the age-specific thresholds for eGFR. This argumentation is supported by observations that GFR may decline with aging without any sign of kidney damage for older living kidney donors, and the risk of mortality increases at higher eGFR among younger people than in elderly individuals $[16,17]$.

Despite controversy over definition, the prevalence of CKD increases dramatically from about $5 \%$ in younger adults (aged 20-39 years) to nearly half of older adults (aged 70 years and above) [18]. This age-gradient can be partially explained by age-related decline in GFR, without major metabolic, vascular or immunologic derangements. Indeed, it has been demonstrated that earlier stages of CKD in the elderly are more likely due to age-associated decline in glomerular filtration than real kidney disease [19]. Some studies even suggest older people with CKD may exhibit slower progression and better outcomes [2023]. For example, in the United States, among patients with eGFR levels $<45 \mathrm{~mL} / \mathrm{min}$ per $1.73 \mathrm{~m}^{2}$, older patients were less likely to have an annual decline in eGFR of $>3$ $\mathrm{mL} / \mathrm{min}$ per $1.73 \mathrm{~m}^{2}$ compared to younger patients [20]. In Europe, a collaborative study enrolling 1248 patients with stage 3-4 CKD, the risk of ESRD was higher than the risk of death without ESRD for ages $<60$ years, independent of eGFR levels. The ESRD risk diminished with aging except in patients between 65 and 75 years with eGFRs of $25-35 \mathrm{~mL} / \mathrm{min}$ per $1.73 \mathrm{~m}^{2}$, and in patients 
up to 85 years with an eGFR $<15 \mathrm{~mL} / \mathrm{min}$ per $1.73 \mathrm{~m}^{2}$ [21]. In the United Kingdom, a prospective observational study comparing the impact of old age on outcomes in 2,667 CKD patients with eGFR $<60 \mathrm{~mL} / \mathrm{min} / 1.73 \mathrm{~m}^{2}$ found those under 55 years had higher risk of renal replacement therapy (RRT) than death, compared to those $>75$ years [22]. Consistent with the above results, we have observed that among 430 patients with stage 3-5 CKD, those aged between 20-39 years and 40-64 years, compared to $\geq 75$ years, exhibited a higher risk of ESRD. This finding suggests old age could be a positive modifier of renal outcome, independently of eGFR and proteinuria [23]. That being said, there is no denying that the incidence of ESRD has been highest among older people, in particular those aged 75 years or over [24, 25]. As populations are getting older at a faster pace, further studies are needed to elucidate this paradox and determine whether differences in case mix or co-morbid burdens are involved in variability of ESRD risk associated with older age.

\section{Specific mechanisms for renal aging}

\section{Renin-angiotensin system (RAS) activity}

In humans, studies have shown a progressive decline in systemic RAS activity with aging, as represented by plasma renin and aldosterone levels [26-28]. Conversely, in experimental animals, the activity of intrarenal RAS, as reflected by urinary angiotensinogen [29], increased despite a decline in the circulating RAS. Additionally, intravenous infusion of angiotensin I led to reduction in glomerular filtration and plasma flow rates, especially in older animals [30]. Such increased sensitivity to RAS stimulation may exacerbate age-associated decline of renal function in the face of RAS stimuli such as hypovolemia, hypotension or sodium restriction. Changes in intrarenal RAS activity with aging may also precipitate an altered response to RAS blockade. For example, the protective effects of angiotensin-converting enzyme (ACE) inhibitors on glomerulosclerosis and albuminuria are blunted in aged animals [31]. And the hypotensive effect exerted by these drugs are less prominent in older hypertensive patients compared to younger counterparts [32].

Apart from its effect on hemodynamics, age-related RAS dysregulation has been implicated in mitochondrial reduction-oxidation (redox) changes and the formation of excessive free radicals, both of which play a part in renal fibrogenesis [33]. In the kidney, knockout of the Agtrla gene that encodes angiotensin II type 1a (AT1a) receptor is associated with an increased number of mitochondria and upregulation of the prosurvival genes nicotinamide phosphoribosyltransferase (Nampt) and sirtuin 3 (Sirt3)
[34]. And RAS blockade with enalapril and losartan protected against mitochondrial dysfunction in aged animals [35]. The mitochondrial-antioxidant contents including nitric oxide synthase, manganese-superoxide dismutase and cytochrome oxidase activities, and uncoupling protein-2 are higher in spontaneously hypertensive rats treated with angiotensin II receptor blockers (ARBs) than those with $\mathrm{Ca}^{2+}$ channel blockade [36]. Moreover, another prosurvival factor, sirtuin 1 (SIRT1), has been shown to attenuate oxidative stress in aged kidneys through suppression of AT1 receptor expression both in vitro and in vivo [37]. Mechanistic studies in human glomerular mesangial cells have also demonstrated that angiotensin II induces the shortening of telomere lengths, P53 and P21 expression, as well as cell cycle arrest. All of these effects are major mechanisms of cell senescence and could be overcome by the treatment with ARB [38].

\section{Chronic inflammation}

Numerous studies have demonstrated that age-related dysregulation of the immune system, so called immunosenescence, is prevalent in normal older individuals. For instance, healthy elderly adults have increased levels of interleukin (IL)-1 $\beta$, IL-6, IL- 8, IL-18, $\mathrm{C}$-reactive protein, and tumor necrosis factor- $\alpha$, as well as a decrease in IL-10 [39,40]. The elderly also shows a shift response from a $\mathrm{T}$ helper (Th)-1 cytokine to a Th-2 cytokine [41], accompanied by an increase in Th-17 cells and a decrease in regulatory $\mathrm{T}$ cells [42]. Additionally, several inflammasomes have been identified in the aging kidneys, in association with high levels of toll-like receptor-4 and IL-1 receptor. The expression of inflammasome components such as nucleotide-binding domain leucine-rich repeat (NLR), NLR pyrin domaincontaining protein 3 (NLRP3), NLR family caspase recruitment domain-containing protein 4 (NLRC4), and pro-caspase- 1 are significantly upregulated in the aging rat kidney [43]. Another study by Sato et al. showed that superaged mice would spontaneously develop renal tertiary lymphoid tissues (TLTs), which may promote inflammatory and fibrotic responses in the kidney [44]. All of these changes causing imbalance of inflammatory cells and associated cytokines are known to aggravate age-related decline in renal function [45, 46].

\section{Dysfunctional signal transduction}

\section{Klotho and Wnt/ $\beta$-catenin signaling}

The anti-aging protein, Klotho, is highly expressed in the tubular epithelium of normal adult kidneys and plays a crucial role in modulating diverse age-associated 
pathways. For example, Klotho is an antagonist of Wnt/ $\beta$ catenin signaling whose activation promotes renal fibrogenesis. Overexpression of Klotho can also abolish the fibrogenic effects of transforming growth factor- $\beta 1$ [47]. As Klotho levels declines with aging, Wnt/ $\beta$-catenin signaling increases, promoting renal fibrosis and vascular calcification $[48-50]$.

\section{Peroxisome proliferator-activated receptor $(P P A R)-\gamma$}

Peroxisome proliferator-activated receptor- $\gamma($ PPAR- $\gamma$ ) is a nuclear receptor with activity that decreases with aging [51]. PPAR- $\gamma$ agonists not only increase Klotho expression but also reduce oxidative stress and improve vascular function in aging rats [52]. Increased PPAR- $\gamma$ expression by pioglitazone or baicalin suppresses ageassociated inflammation through blocking proinflammatory nuclear factor- $\kappa \mathrm{B}(\mathrm{NF}-\kappa \mathrm{B})$ activation in aged rat kidney [53].

\section{Oxidative stress}

Aging is associated with increased oxidative stress which in turn results in tissue damage and accelerates aging process [54]. Increased mitochondrial oxidative phosphorylation, as well as reduced levels of catalase, $\mathrm{Cu} / \mathrm{Zn}$-superoxide dismutase, and glutathione reductase have been linked with a reduced antioxidant capacity in the aging kidney [55, 56]. All of these changes impair the electron transport chain in mitochondria, leading to the progressive failure of mitochondrial bioenergetics and homeostasis [57]. SIRT1 is a nicotinamide adenine dinucleotide ${ }^{+}$-dependent deacetylase which plays a role in redox defense, but its level is reduced with aging. Kume et al. demonstrated that caloric restriction protects the aging kidney by preserving renal Sirtl expression and preventing mitochondrial autophagy [58]. Augmented expression of Sirtl could enhance the ability of renal interstitial cells to resist the oxidizing medullary environment and produce antifibrotic and antiapoptotic actions [59]. Another study by Chuang et al. confirmed that podocyte-specific Sirtl knockdown mice were associated with reduced activation of the PPAR- $\gamma$ coactivator-1 $\alpha$ (PGC-1 $\alpha$ ), forkhead box O3, forkhead box $\mathrm{O} 4$, and p65 NF- $\mathrm{BB}$, through SIRT1-mediated deacetylation. These suggest that dysregulation of SIRT1 results in activation of downstream pathways of oxidant stress, cell death, and inflammation in podocytes [60]. SIRT3 is another mitochondrial deacetylase that can increase mitochondria number and upregulate the prosurvival genes, thereby protecting cells from oxidative stress-mediated injury [61]. Benigni et al. found that angiotensin II was able to downregulate Sirt3 mRNA expression in cultured tubular epithelial cells and this effect could be inhibited by AT1 receptor antagonist [34]. Together, the sirtuin family of proteins may be a potential target for patients with age-related decline in kidney function.

\section{Vascular changes}

Aging kidneys are characterized by progressive narrowing of renal vasculature as exemplified by the prevalence of renal artery narrowing or atherosclerosis which increases from $0.4 \%$ in the $18-29$ years age group to $25 \%$ in the 60-76 years age group [62]. At the microvascular level, increased shunting of cortical blood to the medullary circulation, atrophy of afferent and efferent vessels, and loss of peritubular capillaries lead to a gradual reduction in the circulation of nephron [63]. Using "hypoxia-responsive" reporter of the transgenic rats, age-related expansion of hypoxia was identified in all areas of the kidney, particularly in the cortex. The degree of hypoxia correlated with upregulation of vascular endothelial growth factor and glucose transporter-1, highlighting the involvement of hypoxia-inducible factor and its target genes in the aging kidney [64].

There is a tendency toward developing disproportionate vasoconstriction of the renal vasculature in the elderly. This is likely caused by increased sympathetic tone and propensity to vasoconstrictor effects of angiotensin II, endothelin, and platelet-activating factor, as well as decreased response to renal vasodilators, such as atrial natriuretic peptide, nitric oxide, and amino acids. Such imbalance which is in favor of vasoconstrictive force makes the old kidney difficult to maintain its normal renal plasma flow, thereby increasing susceptibility to nephrotoxic injury $[65,66]$.

\section{Telomere shortening}

Although telomere length declines with age, it remains controversial whether telomere length reflects the byproduct of aging or a biomarker that can influence biological conditions, delay senescence and promote longevity [67]. Most studies favor that telomere shortening is the result of aging which indicate the state of cell senescence. However, some studies point out that telomere shortening makes the aged kidney more vulnerable to injury and causing maladaptive repair. Telomerase is a reverse transcriptase enzyme complex that adds DNA sequence repeats to DNA strands in the telomere regions. Telomerase contains 2 major components, TerT and TerC, which together prevent telomere shortening. Telomerase gene therapy has been shown to delay aging and increase longevity in aged mice [68]. Some studies have also demonstrated delayed recovery from renal ischemia-reperfusion injury in mice 
with deletion of either TerC or TerT, suggesting a crucial role of telomerase on renal regeneration after injury [69].

\section{Epidemiology, risk factors, progression and outcomes of CKD in older patients}

Several large-scale studies have reported the prevalence of CKD increases disproportionately with age [18, 70]. The National Health and Nutrition Examination Survey (NHANES) during 1999 and 2004 in the United States reported $46.8 \%$ of people aged 70 and older, compared to $6.71 \%$ in those between $40-59$ years of age, had moderately severe CKD as defined by an eGFR $<60$ $\mathrm{mL} / \mathrm{min} / 1.73 \mathrm{~m}^{2}$ calculated by the Chronic Kidney Disease Epidemiology Collaboration (CKD-EPI) equation [18]. The National Kidney Foundation's Kidney Early Evaluation Program (KEEP) during 2000 and 2008 also reported the prevalence of CKD in people 65 years and older was approximately $44 \%$, with the highest representation being observed in those over age 80. Most of them (77\%) belonged to CKD stage 3 and only 5\% were stage 4 [70]. In other countries, the prevalence of CKD in the elderly population is similarly high, with as many as $30.5 \%$ of Beijing citizens older than 70 years, and $30.8 \%$ of Canadian older than 65 years showing eGFR $<60 \mathrm{~mL} / \mathrm{min} / 1.73 \mathrm{~m}^{2}$ or markers of kidney damage [71, 72]. In a systematic review comprising 26 populationbased studies, the researchers concluded that the prevalence of CKD in people aged 64 years or older was between $23.4 \%$ and $35.8 \%$ [73]. Consistent with these observations, a prospective cohort study based on 462,293 adults who participated in a standard medical screening program during 1994 and 2006 in Taiwan found 37.2\% of participants aged 65 years or over had an eGFR $<60$ $\mathrm{mL} / \mathrm{min} / 1.73 \mathrm{~m}^{2}$ [74]. Another prospective cohort study integrating community-based screening program of 106,094 adults in northern Taiwan confirmed the high prevalence of total CKD (15.46\%) and CKD stages 3-5 $(9.06 \%)$, which occurs predominantly in older individuals [75].

Table 2. Risk factors for chronic kidney disease in the elderly.

\begin{tabular}{l|l}
\hline Modifiable risk factors & Non-modifiable risk factors \\
\hline - Acute kidney injury & $\bullet$ Demographics (age, gender) \\
$\quad$ (perioperative cardiac dysfunction, sepsis, & $\bullet$ Race \& ethnicity \\
obstructive uropathy, hypovolemia, NSAID use, & $\bullet$ Low birth weight \\
radiocontrast media, pauci-immune & • Family aggregation \\
$\quad$ glomerulonephritis) & $\bullet$ Hereditary disease \\
- Cardiovascular disease & \\
(heart failure, renal artery stenosis) & \\
- Diabetes mellitus & \\
- Hypertension & \\
- Proteinuria & \\
- Obesity & \\
- Hyperlipidemia & \\
- Hyperuricemia & \\
\hline
\end{tabular}

Only a few studies have focused on risk factors for development of CKD in older adults, despite a plethora of data within general population (Table 2) [76, 77]. As mentioned earlier, CKD is a common disorder among aging populations and the cause of which is likely multifactorial. The presence of diabetes, hypertension and glomerulonephritis, dyslipidemia and cardiovascular diseases, as well as inappropriate use of non-steroidal anti-inflammatory drugs (NSAIDs) or herbal medicine all play a part in triggering damage to the aged kidney with decreased physiological reserve [78]. Additionally, acute kidney injury (AKI), which often occurs during the course of acute illnesses is becoming a prominent risk factor for subsequent development of CKD and ESRD [79, 80]. More and more patients with critical conditions are saved at the expense of AKI. In a systematic review and metaanalysis comprising 17 studies of patients with AKI, $31.3 \%$ of surviving elderly patients ( $\geqq 65$ years) did not recover kidney function compared to $26 \%$ of younger patients [81]. These findings indicate elderly patients are less likely to recover from acute kidney injury (AKI), 
which likely reflects decreased reparative and regenerative potential of the aged kidney $[77,79,80]$.

Table 3. Treatment goals for glycemia, blood pressure, and dyslipidemia in older adults with or without diabetes.

\begin{tabular}{|c|c|c|c|c|c|c|}
\hline $\begin{array}{l}\text { Diabetic patient } \\
\text { characteristics/ } \\
\text { health status (ADA } \\
\text { guideline, 2019) }\end{array}$ & Rationale & $\begin{array}{l}\text { HbA1C } \\
\text { goal }\end{array}$ & $\begin{array}{l}\text { Fasting or } \\
\text { preprandial } \\
\text { glucose } \\
(\mathrm{mg} / \mathrm{dL})\end{array}$ & $\begin{array}{l}\text { Bedtime } \\
\text { glucose } \\
(\mathrm{mg} / \mathrm{dL})\end{array}$ & $\begin{array}{l}\text { Blood } \\
\text { pressure } \\
(\mathrm{mmHg})\end{array}$ & Lipids \\
\hline $\begin{array}{l}\text { Healthy } \\
\text { (few coexisting chronic } \\
\text { illnesses, intact cognitive } \\
\text { and functional status) }\end{array}$ & $\begin{array}{l}\text { Longer remaining life } \\
\text { expectancy }\end{array}$ & $<7.5 \%$ & $90-130$ & $90-150$ & $<140 / 80$ & $\begin{array}{l}\text { Statin unless } \\
\text { contraindicated } \\
\text { or not tolerated }\end{array}$ \\
\hline $\begin{array}{l}\text { Complex/intermediate } \\
\text { (multiple coexisting chronic } \\
\text { illnesses or } 2+\text { instrumental } \\
\text { ADL impairments or mild to } \\
\text { moderate cognitive } \\
\text { impairment) }\end{array}$ & $\begin{array}{l}\text {-Intermediate remaining } \\
\text { life expectancy, } \\
\text { - high treatment burden, } \\
\text { - hypoglycemia } \\
\text { vulnerability, } \\
\text { - fall risk } \\
\end{array}$ & $<8.0 \%$ & $90-150$ & $100-180$ & $<140 / 80$ & $\begin{array}{l}\text { Statin unless } \\
\text { contraindicated } \\
\text { or not tolerated }\end{array}$ \\
\hline $\begin{array}{l}\text { Very complex/poor health } \\
\text { (long-term care or end-stage } \\
\text { chronic illnesses or moderate } \\
\text { to severe cognitive } \\
\text { impairment or } 2+\mathrm{ADL} \\
\text { dependencies) }\end{array}$ & $\begin{array}{l}\text { Limited remaining life } \\
\text { expectancy makes } \\
\text { benefit uncertain }\end{array}$ & $<8.5 \%$ & $100-180$ & $110-200$ & $<150 / 90$ & $\begin{array}{l}\text { Consider } \\
\text { likelihood of } \\
\text { benefit with } \\
\text { statin (secondary } \\
\text { prevention more } \\
\text { than primary) }\end{array}$ \\
\hline $\begin{array}{l}\text { Non-diabetic patient } \\
\text { characteristics }\end{array}$ & Blood pressure $(\mathrm{mmHg})$ & & & & Reference & \\
\hline $\begin{array}{l}<65 \mathrm{y} \\
\geq 65 \mathrm{y}\end{array}$ & $\begin{array}{l}<130 / 80 \\
<130 / 80\end{array}$ & & & & \multicolumn{2}{|c|}{ ACC/AHA guideline, 2017} \\
\hline $\begin{array}{l}<65 \mathrm{y} \\
\geq 65 \mathrm{y}\end{array}$ & $\begin{array}{l}<130 / 80 \\
<140 / 80\end{array}$ & & & & \multicolumn{2}{|c|}{ ESC/ESH guideline, 2018} \\
\hline $\begin{array}{l}\text { Non-diabetic patient } \\
\text { characteristics }\end{array}$ & LDL-C mg/dL & & & & \multicolumn{2}{|l|}{ Reference } \\
\hline $\begin{array}{l}40-75 y \\
>75 y\end{array}$ & $\begin{array}{l}\geq 70-<190 \\
\text { Clinical assessment, risk }\end{array}$ & scussion & & & \multicolumn{2}{|c|}{ ACC/AHA guideline, 2019} \\
\hline$>65 y$ & \multicolumn{4}{|c|}{$\begin{array}{l}\text { Clinical assessment, risk discussion } \\
\text { with ASCVD in the same way as for younger patients } \\
\text { 2. Treatment with statins is recommended for } \\
\text { primary prevention, according to the level of risk, in older } \\
\text { people aged } \leqq 75 \text { years. } \\
\text { 3. Initiation of statin treatment for primary prevention in older } \\
\text { people aged }>75 \text { years may be considered, if at high-risk or } \\
\text { above. } \\
\text { 4. The statin should be started at a low dose if there is } \\
\text { significant renal impairment and/or the potential for drug } \\
\text { interactions, and then titrated upwards to achieve LDL-C } \\
\text { treatment goals. }\end{array}$} & \multicolumn{2}{|c|}{ ESC/ESH guideline, 2019} \\
\hline
\end{tabular}

Several studies have reported predictors of renal progression to ESRD in the elderly. Nicola et al. identified high proteinuria level as a strong prognostic factor of ESRD development in older patients with incipient CKD [21]. Obi et al. found age as a determinant of mortality, whereas overt proteinuria was strongly associated with ESRD in the elderly [82]. They further showed the incidence of ESRD was appreciably higher than that of death before RRT in patients with advanced CKD and overt proteinuria. The mechanism whereby proteinuria causes progressive kidney damage has been described elsewhere [83]. Given its clinical significance, proteinuria has been incorporated into Tangri et al.'s predictive model for progression of CKD to ESRD, the 4-variable Kidney Failure Risk Equation (KFRE) [84-86]. Based on the formula, older patients with CKD display a lower 
probability of renal failure, compared to younger counterparts. These findings contradict the assumption that GFR declines by $10 \%$ per decade after the fourth decade, suggesting that decline in GFR with age might not be inevitable, at least for those without concomitant diabetes or hypertension. In another study, older patients were found less likely to develop ESRD than their younger counterparts with similar levels of eGFR, even after adjustment for the competing risk of mortality [23]. Nevertheless, older people in particular those $\geqq 75$ years of age constitute the largest percentage of incident patients with ESRD. The explanation for this paradox remains unclear, although in a large representative sample from the Unites States Medicare beneficiaries, up to $25.2 \%$ of ESRD patients were identify having a prior history of AKI [87]. Therefore, from a preventive perspective, it seems imperative that every efforts should be made to provide quality care for elderly people with or without existing CKD, not only to save lives [88-91], but to maintain quality of life by abolishing the transition of AKI to CKD and ESRD.

\section{Treatment and care management for the elderly}

Taiwan will become a super-aged society by 2026 when at least 20 percent of the population are 65 years or older (National Development Council. Population projections for Taiwan, assessed at https://pop-proj.ndc.gov.tw/ main en/ June 12, 2020). The prevalence of elderly CKD is expected to increase further if the current preventive measures against CKD remains unchanged. It has been suggested that age-specific care considerations should be incorporated into the scope of management for elderly patients with CKD $[92,93]$. To name just a few, GFR thresholds for diagnosing CKD may be adjusted downward to $45-50 \mathrm{~mL} / \mathrm{min} / 1.73 \mathrm{~m}^{2}$, based on mortality outcomes stratified by levels of GFR in the general population $[9,94]$. The prescription of NSAIDs may be subjected to tighter regulations in the elderly with CKD [95].

There are few evidence-based guidelines available for preventing CKD progression in the elderly. More studies in this regard are warranted. The following are some selected topics which merit special attention for the medical professionals.

\section{Modification of risk factors}

For older people with or without CKD, modifiable risk factors or controllable comorbidities should be identified and managed appropriately, irrespective of diabetic status (Table 2). The American Diabetes Association has established a framework of management of glucose, blood pressure and lipids for the diabetic elderly [96, 97]. Three major classes of older patients are included: 1) relatively healthy, 2) those with complex medical histories where self-care may be difficult, and 3) those with very significant comorbid illnesses and functional impairment. As shown in Table 3, screening for diabetes and prediabetes is necessary for people over 65 years, and even earlier in overweight people over 45 years by using either a fasting plasma glucose test, hemoglobin A1c, or oral glucose tolerance test every 1-3 years. Because the elderly has vulnerability to hypoglycemia, glycemic goals for older adults may be relaxed using individualized criteria according to comorbidities they have. Treatment of hypertension and dyslipidemia should also be tailored in older adults according to the time frame of benefit, taking into account patient characteristics such as individual's cognitive and functional status, risk for cardiovascular events and tolerance to antihypertensive drug therapy. Lipid-lowering therapy should also be used for management of dyslipidemia unless contraindicated or not tolerated. For non-diabetic elderly patients, treatment of hypertension and dyslipidemia can follow the same guidance as for diabetic counterparts [98-102]. The general principles of 'start low and go slow' and 'avoid potentially inappropriate medications' endorsed by the geriatric societies should be adopted, regardless of diabetic status, to prevent adverse drug reactions or events [98-101, 103, 104].

\section{Prevention of AKI}

AKI, even if followed by renal recovery, is emerging as a prominent risk factor for the future development of CKD and ESRD [79, 80]. A cohort of 233,803 hospitalized, older patients without previous ESRD or AKI, showed that the hazard ratio for developing ESRD was 41.2 for patients with AKI and CKD compared to those without kidney disease. Among patients who progressed to ESRD, $25.2 \%$ had a previous history of AKI, indicating that episodes of AKI during hospitalization may accelerate progression of renal disease, particularly those with CKD [87]. Because of few proven pharmacological treatments for AKI in the elderly [105], implementation of preventive measures to protect kidney function is clearly a better strategy. Recognizing the increased vulnerability and potential risk factors of the elderly is crucial to establish pragmatic approaches to prevent AKI. Some of these include investigating applicable formula or biomarkers to detect early AKI, treating diabetes and hypertension, managing dyslipidemia and cardiovascular diseases, preventing sepsis, and avoiding contrast nephrotoxicity and abuse of NSAIDs [106]. Of note, blood pressure levels should be monitored periodically to avoid unstable hemodynamics and inadvertent AKI [107, 108], 
especially for those with poor medical conditions. Other general measures for the prevention of AKI are listed in Table 4.

Table 4. Preventive strategies for acute kidney injury in the elderly.

- Identify high risk clinical settings

Preexisting CKD, cardiac failure, malnutrition, hypovolemia, perioperative period of cardiovascular surgery

- Avoid nephrotoxic insults

Prevent contrast-induced nephropathy

Restrain frequent radiocontrast-based procedures

Use lowest dose in the shortest time possible (analgesics)

- Keep optimal hemodynamics during treatment of hypertension

Avoid use of diuretics and/or NSAIDs on top of ACE inhibitors or ARBs

Target systolic blood pressure level around 120-140 mmHg

- Prevent sepsis development by timely and effective antimicrobial therapy

\section{Stabilization of CKD progression}

Novel drug development for kidney diseases has been limited over the last few decades. Current practice guidelines recommend blood pressure control with RAS blockade as the gold standard therapy for patients with proteinuric CKD. However, blocking the RAS by either ACE inhibitors or ARBs slows but does not stop the progression of kidney disease [80, 109-111]. The old drug pentoxifylline, a nonselective phosphodiesterase inhibitor, could reduce the occurrence of AKI as determined by attenuation of serum creatinine rise [112, 113], associate with reduction of neonatal sepsis related metabolic acidosis [114], and display add-on renoprotective activities when administered in conjunction with RAS blockade [110, 111]. The current anti-diabetic agent, PPAR- $\gamma$ agonist may have some protective effects on kidney diseases and renal aging as well as amelioration of hyperuricemic nephropathy [115118]. Sodium-glucose cotransporter-2 (SGLT2) inhibitors are a new class of glucose-lowering medications that have been approved for use in patients with type 2 diabetes. These drugs have been shown to exert beneficial effects on cardiovascular events and renal endpoints, possibly through extra-glycemic mechanisms [119]. SGLT2 inhibition increases glucose and sodium delivery to the macula densa, which induces the tubuloglomerular feedback. This effect results in afferent arteriole vasoconstriction and a reduction in intraglomerular pressure [120]. Another multinational observational cohort study reported that using SGLT2 inhibitor therapy was associated with a lower eGFR decline and lower risk of major kidney events compared with initiation of other glucose-lowering drugs [121]. Importantly, trials of SGLT2 inhibitors in non-diabetic progressive kidney disease are in progress [122]. (DAPA-CKD, A Study to Evaluate the Effect of Dapagliflozin on Renal Outcomes and Cardiovascular Mortality in Patients with Chronic Kidney Disease; EMPA-KIDNEY, The Study of Heart and Kidney Protection with Empagliflozin). No subgroup analyses have yet been performed in older people to explore the effects of SGLT2 inhibitors to prevent CKD development or progression, irrespective of diabetic status. More novel therapeutic agents such as Klotho agonists and drugs targeting cellular senescence including navitoclax, dasatinib and quercetin have been developed but more investigations are needed to confirm their clinical utility $[123,124]$.

\section{Decision on dialysis initiation}

Elderly patients with advanced CKD have to face with the difficult decision-making about dialysis initiation as renal function declines toward ESRD. The choices have become even tougher in the wake of escalating financial burden imposed by the long-term nature of treatment. Most guidelines advocate to postpone dialysis initiation until the eGFR has reached $5-10$ or $\leq 6 \mathrm{ml} / \mathrm{min} / 1.73 \mathrm{~m}^{2}$ for asymptomatic patients, i.e., deferring the initiation of long-term dialysis until absolutely indicated [125]. This paradigm shift is supported by the IDEAL study [126], 
and a subsequent study exploring the optimal timing of dialysis initiation among older adults with advanced CKD which showed that compared with medical management, dialysis initiation at eGFR $<6 \mathrm{ml} / \mathrm{min} / 1.73 \mathrm{~m}^{2}$ associated with a higher median life expectancy of 26,25 , and 19 months for patients aged 65,75 , and 85 years, respectively [127]. Conversely, conservative kidney management without provision of dialysis may be an alternative option for some older patients with poor health conditions. For example, in a study included 349,440 patients aged 70 years and over at the time of initiation of dialysis, institutionalized individuals had higher mortality as compared to non-instutionalized counterparts in the same age group. The researchers concluded that for frail elderly with advanced CKD, especially those with multiple comorbidities, or major neurocognitive disorders, conservative management with palliative or end-of-life care should be considered due to lack of therapeutic benefits of dialysis therapy [128]. Other studies have also observed that patients in nursing home or higher severity of frailty at dialysis initiation are associated with a substantial, post-dialysis decline in functional status and patient survival, respectively $[129,130]$. Thus, with backup from palliative care professionals, later start of dialysis or use of conservative management, including reduced dose or frequency of dialysis, may be considered for patients complicated by severe functional or cognitive impairments [45, 130, 131]. In contrast, for robust elderly patients with ESRD whose activities of daily living remain independent, there is no reason why long-term dialysis therapy should not be initiated according to standard treatment guidelines (Fig. 1).

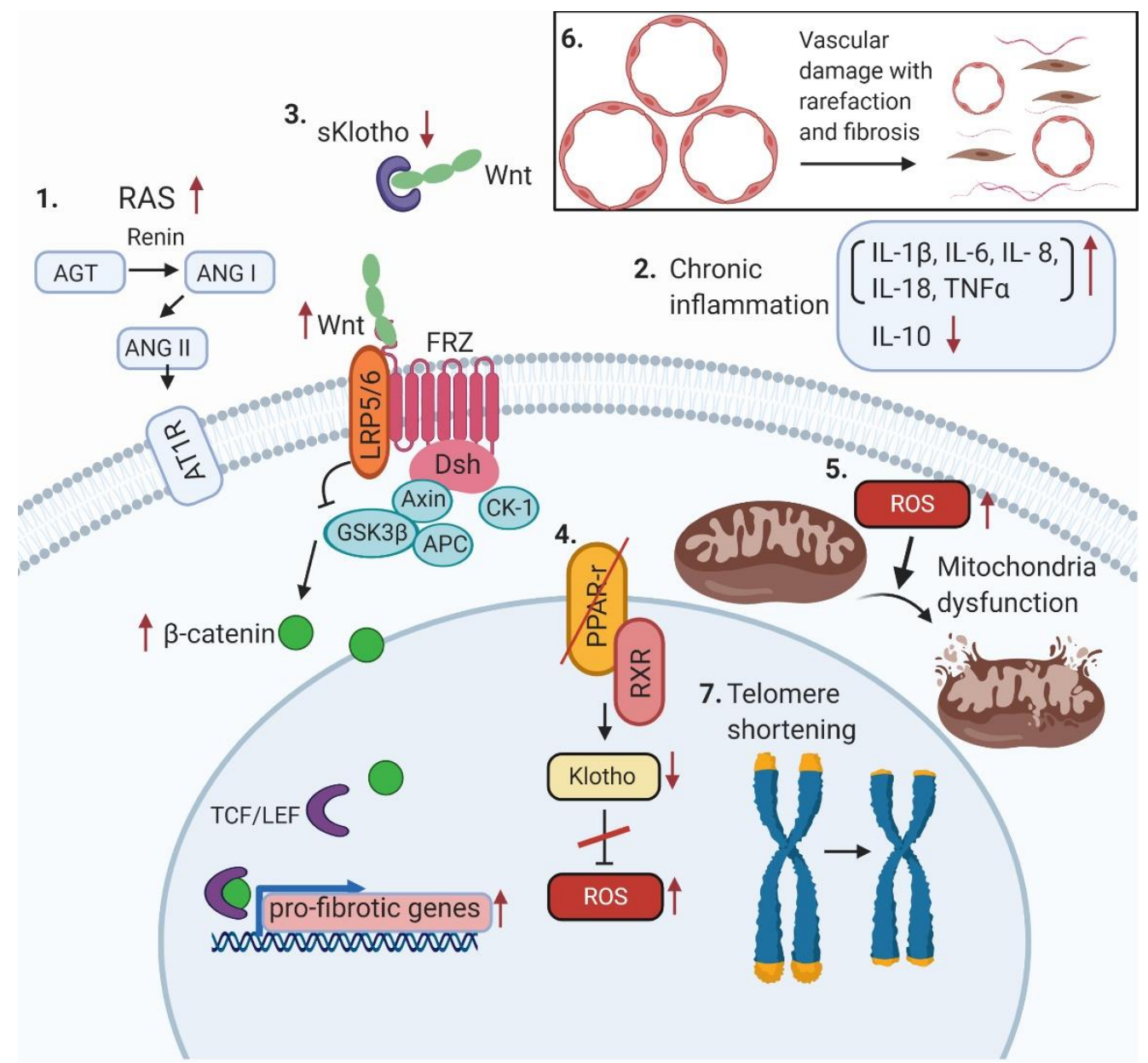

Figure 1. Molecular mechanisms of renal aging. (1) Activation of RAS system (2) Chronic inflammation (3) Decreased Klotho expression and activation of Wnt/ $\beta$-catenin signaling (4) Decreased PPAR- $\gamma$ activity (5) Increased oxidative stress and mitochondrial dysfunction (6) Vascular damage (7) Telomere shortening. Abbreviations: AGT, angiotensinogen; ANG I, angiotensin I; ANG II, angiotensin II; AT1R, angiotensin II type 1 receptor; FRZ, Frizzled family receptor; GSK, glycogen synthase kinase; LRP5/6, lipoprotein receptor-related protein 5/6; RXR, retinoid X receptor; ROS, reactive oxygen species; $\mathrm{TCF} / \mathrm{LEF}$, transcription factors involved in the Wnt signaling pathway. 


\section{Conclusions and perspectives}

The aged kidney undergoes structural and functional changes which are indistinguishable from that of incipient kidney diseases. Differentiating these two conditions is crucial in implementing available strategies to prevent the development of kidney disease. Apart from mechanistic research need on kidney senescence, there exist knowledge gaps in caring for older patients with CKD. First, most clinical trials for renal progression have excluded older patients, leading to competing therapeutic priorities, and the resultant clinical guidelines might not be generalizable to all persons involved. Second, elderly people are vulnerable to superimposed AKI, yet effective measures or treatment tackling AKI to CKD transition or AKI on CKD progression have not been explored to the fullest extent possible. Last but not least, it remains a challenge for clinicians when it comes to the decisionmaking of dialysis initiation. Studies addressing the risk of mortality, quality of life and functional capacity in geriatric patients are desperately required so that those who are robust can opt for dialysis whereas those complicated by existing functional or cognitive impairments may consider conservative management.

\section{Acknowledgements}

Y.H.C. was supported by MOST (104-2314- B-002-119MY3, 107-2314-B-002-020, 108-2314-B-002-060-), NTUH (107-003974) and the Mrs. Hsiu-Chin Lee Kidney Research Foundation. Y.M.C. was supported by MOST (105-2314-B-002-098-MY3,108-2314-B-002-064-MY3) and the Ta-Tung Kidney Foundation.

\section{References}

[1] Fraser SDS, Roderick PJ (2019). Kidney disease in the Global Burden of Disease Study 2017. Nat Rev Nephrol, 15:193-194.

[2] Imai E, Matsuo S (2008). Chronic kidney disease in Asia. Lancet, 371:2147-2148.

[3] Romagnani P, Remuzzi G, Glassock R, Levin A, Jager KJ, Tonelli M, et al. (2017). Chronic kidney disease. Nat Rev Dis Primers, 3:17088.

[4] Okusa MD, Davenport A (2014). Reading between the (guide)lines--the KDIGO practice guideline on acute kidney injury in the individual patient. Kidney Int, 85:39-48.

[5] Epstein M (1996). Aging and the kidney. J Am Soc Nephrol, 7:1106-1122.

[6] Gourtsoyiannis N, Prassopoulos P, Cavouras D, Pantelidis N (1990). The thickness of the renal parenchyma decreases with age: a CT study of 360 patients. AJR Am J Roentgenol, 155:541-544.

[7] Hollenberg NK, Adams DF, Solomon HS, Rashid A, Abrams HL, Merrill JP (1974). Senescence and the renal vasculature in normal man. Circ Res, 34:309316.

[8] Hommos MS, Glassock RJ, Rule AD (2017). Structural and Functional Changes in Human Kidneys with Healthy Aging. J Am Soc Nephrol, 28:28382844.

[9] Denic A, Glassock RJ, Rule AD (2016). Structural and Functional Changes With the Aging Kidney. Adv Chronic Kidney Dis, 23:19-28.

[10] O'Sullivan ED, Hughes J, Ferenbach DA (2017). Renal aging: causes and consequences. J Am Soc Nephrol, 28:407-420.

[11] Rule AD, Amer H, Cornell LD, Taler SJ, Cosio FG, Kremers WK, et al. (2010). The association between age and nephrosclerosis on renal biopsy among healthy adults. Ann Intern Med, 152:561-567.

[12] Eckardt KU, Berns JS, Rocco MV, Kasiske BL (2009). Definition and classification of CKD: the debate should be about patient prognosis--a position statement from KDOQI and KDIGO. Am J Kidney Dis, 53:915-920.

[13] O'Hare AM, Bertenthal D, Covinsky KE, Landefeld CS, Sen S, Mehta K, et al. (2006). Mortality risk stratification in chronic kidney disease: one size for all ages? J Am Soc Nephrol, 17:846-853.

[14] Coresh J, Turin TC, Matsushita K, Sang Y, Ballew $\mathrm{SH}$, Appel LJ, et al. (2014). Decline in estimated glomerular filtration rate and subsequent risk of endstage renal disease and mortality. JAMA, 311:25182531.

[15] Pavkov ME, Nelson RG (2019). Estimating GFR in the elderly-new approaches to an old problem. Kidney Int Rep, 4:763-765.

[16] Delanaye P, Jager KJ, Bökenkamp A, Christensson A, Dubourg L, Eriksen BO, et al. (2019). CKD: A call for an age-adapted definition. J Am Soc Nephrol, 30:1785-1805.

[17] Trachtman H (2020). Age-dependent definition of CKD. J Am Soc Nephrol, 31:447.

[18] Coresh J, Selvin E, Stevens LA, Manzi J, Kusek JW, Eggers P, et al. (2007). Prevalence of chronic kidney disease in the United States. JAMA, 298:2038-2047.

[19] Poggio ED, Rule AD, Tanchanco R, Arrigain S, Butler RS, Srinivas T, et al. (2009). Demographic and clinical characteristics associated with glomerular filtration rates in living kidney donors. Kidney Int, 75:1079-1087.

[20] O'Hare AM, Choi AI, Bertenthal D, Bacchetti P, Garg AX, Kaufman JS, et al. (2007). Age affects outcomes in chronic kidney disease. J Am Soc Nephrol, 18:2758-2765.

[21] De Nicola L, Minutolo R, Chiodini P, Borrelli S, Zoccali C, Postorino M, et al. (2012). The effect of increasing age on the prognosis of non-dialysis patients with chronic kidney disease receiving stable nephrology care. Kidney Int, 82:482-488.

[22] Raman M, Green D, Middleton RJ, Kalra PA (2018). Comparing the impact of older age on outcome in chronic kidney disease of different etiologies: a prospective cohort study. J Nephrol, 31:931-939. 
[23] Chou YH, Yen CJ, Lai TS, Chen YM (2019). Old age is a positive modifier of renal outcome in Taiwanese patients with stages 3-5 chronic kidney disease. Aging Clin Exp Res.

[24] McCullough KP, Morgenstern H, Saran R, Herman WH, Robinson BM (2019). Projecting ESRD incidence and prevalence in the United States through 2030. J Am Soc Nephrol, 30:127-135.

[25] Lin YH HC, Kao CC, Chen TW, Chen HH, Hsu CC, et al. (2014). Incidence and prevalence of ESRD in Taiwan Renal Registry Data System (TWRDS): 20052012. Acta Nephrologica, 28:65-68.

[26] Noth RH, Lassman MN, Tan SY, Fernandez-Cruz A, Jr., Mulrow PJ (1977). Age and the renin-aldosterone system. Arch Intern Med, 137:1414-1417.

[27] Weidmann P, De Myttenaere-Bursztein S, Maxwell $\mathrm{MH}$, de Lima J (1975). Effect on aging on plasma renin and aldosterone in normal man. Kidney Int, 8:325-333.

[28] Mulkerrin E, Epstein FH, Clark BA (1995). Aldosterone responses to hyperkalemia in healthy elderly humans. J Am Soc Nephrol, 6:1459-1462.

[29] Kobori H, Navar LG (2011). Urinary angiotensinogen as a novel biomarker of intrarenal renin-angiotensin system in chronic kidney disease. Int Rev Thromb, 6:108-116.

[30] Thompson MM, Oyama TT, Kelly FJ, Kennefick TM, Anderson S (2000). Activity and responsiveness of the renin-angiotensin system in the aging rat. Am J Physiol Regul Integr Comp Physiol, 279:R1787-1794.

[31] Anderson S, Rennke HG, Zatz R (1994). Glomerular adaptations with normal aging and with long-term converting enzyme inhibition in rats. Am J Physiol, 267:F35-43

[32] Anderson S (1997). Ageing and the renin-angiotensin system. Nephrol Dial Transplant, 12:1093-1094.

[33] Vajapey R, Rini D, Walston J, Abadir P (2014). The impact of age-related dysregulation of the angiotensin system on mitochondrial redox balance. Front Physiol, 5:439.

[34] Benigni A, Corna D, Zoja C, Sonzogni A, Latini R, Salio M, et al. (2009). Disruption of the Ang II type 1 receptor promotes longevity in mice. J Clin Invest, 119:524-530.

[35] de Cavanagh EM, Piotrkowski B, Basso N, Stella I, Inserra F, Ferder L, et al. (2003). Enalapril and losartan attenuate mitochondrial dysfunction in aged rats. FASEB J, 17:1096-1098.

[36] de Cavanagh EM, Toblli JE, Ferder L, Piotrkowski B, Stella I, Inserra F (2006). Renal mitochondrial dysfunction in spontaneously hypertensive rats is attenuated by losartan but not by amlodipine. Am J Physiol Regul Integr Comp Physiol, 290:R1616-1625.

[37] Miyazaki R, Ichiki $T$, Hashimoto $T$, Inanaga $K$, Imayama I, Sadoshima J, et al. (2008). SIRT1, a longevity gene, downregulates angiotensin II type 1 receptor expression in vascular smooth muscle cells. Arterioscler Thromb Vasc Biol, 28:1263-1269.

[38] Feng X, Wang L, Li Y (2011). Change of telomere length in angiotensin II-induced human glomerular mesangial cell senescence and the protective role of losartan. Mol Med Rep, 4:255-260.

[39] Costello-White R, Ryff CD, Coe CL (2015). Aging and low-grade inflammation reduce renal function in middle-aged and older adults in Japan and the USA. Age (Dordr), 37:9808.

[40] Castle SC, Uyemura K, Fulop T, Makinodan T (2007). Host resistance and immune responses in advanced age. Clin Geriatr Med, 23:463-479.

[41] Lang PO, Aspinall R (2012). Immunosenescence and herd immunity: with an ever-increasing aging population do we need to rethink vaccine schedules? Expert Rev Vaccines, 11:167-176.

[42] Schmitt V, Rink L, Uciechowski P (2013). The Th17/Treg balance is disturbed during aging. Exp Gerontol, 48:1379-1386.

[43] Song F, Ma Y, Bai XY, Chen X (2016). The expression changes of inflammasomes in the aging rat kidneys. J Gerontol A Biol Sci Med Sci, 71:747-756. Sato Y, Mii A, Hamazaki Y, Fujita H, Nakata H, Masuda K, et al. (2016). Heterogeneous fibroblasts underlie age-dependent tertiary lymphoid tissues in the kidney. JCI Insight, 1:e87680.

[45] Mallappallil M, Friedman EA, Delano BG, McFarlane SI, Salifu MO (2014). Chronic kidney disease in the elderly: evaluation and management. Clin Pract (Lond), 11:525-535.

[46] Wei SY, Pan SY, Li B, Chen YM, Lin SL (2019). Rejuvenation: Turning back the clock of aging kidney. J Formos Med Assoc.

[47] Zhou L, Li Y, Zhou D, Tan RJ, Liu Y (2013). Loss of Klotho contributes to kidney injury by derepression of Wnt/beta-catenin signaling. J Am Soc Nephrol, 24:771-785.

[48] Lim K, Groen A, Molostvov G, Lu T, Lilley KS, Snead D, et al. (2015). Alpha-Klotho expression in human tissues. J Clin Endocrinol Metab, 100:E13081318 .

[49] Nitta K, Nagano N, Tsuchiya K (2014). Fibroblast growth factor $23 /$ klotho axis in chronic kidney disease. Nephron Clin Pract, 128:1-10.

[50] Tan RJ, Zhou D, Zhou L, Liu Y (2014). Wnt/betacatenin signaling and kidney fibrosis. Kidney Int Suppl (2011), 4:84-90.

[51] Erol A (2007). The Functions of PPARs in Aging and Longevity. PPAR Res, 2007:39654.

[52] Wang P, Li B, Cai G, Huang M, Jiang L, Pu J, et al. (2014). Activation of PPAR-gamma by pioglitazone attenuates oxidative stress in aging rat cerebral arteries through upregulating UCP2. J Cardiovasc Pharmacol, 64:497-506.

[53] Lim HA, Lee EK, Kim JM, Park MH, Kim DH, Choi YJ, et al. (2012). PPARgamma activation by baicalin suppresses NF-kappaB-mediated inflammation in aged rat kidney. Biogerontology, 13:133-145.

[54] Vlassara H, Torreggiani M, Post JB, Zheng F, Uribarri J, Striker GE (2009). Role of oxidants/inflammation in declining renal function in chronic kidney disease and normal aging. Kidney Int Suppl:S3-11. 
[55] Miyazawa M, Ishii T, Yasuda K, Noda S, Onouchi H, Hartman PS, et al. (2009). The role of mitochondrial superoxide anion $(\mathrm{O} 2(-))$ on physiological aging in C57BL/6J mice. J Radiat Res, 50:73-83.

[56] Akcetin Z, Erdemli G, Bromme HJ (2000). Experimental study showing a diminished cytosolic antioxidative capacity in kidneys of aged rats. Urol Int, 64:70-73.

[57] Balaban RS, Nemoto S, Finkel T (2005). Mitochondria, oxidants, and aging. Cell, 120:483-495.

[58] Kume S, Uzu T, Horiike K, Chin-Kanasaki M, Isshiki $\mathrm{K}$, Araki S, et al. (2010). Calorie restriction enhances cell adaptation to hypoxia through Sirt1-dependent mitochondrial autophagy in mouse aged kidney. J Clin Invest, 120:1043-1055.

[59] He W, Wang Y, Zhang MZ, You L, Davis LS, Fan H, et al. (2010). Sirt1 activation protects the mouse renal medulla from oxidative injury. $\mathrm{J}$ Clin Invest, 120:1056-1068.

[60] Chuang PY, Cai W, Li X, Fang L, Xu J, Yacoub R, et al. (2017). Reduction in podocyte SIRT1 accelerates kidney injury in aging mice. Am J Physiol Renal Physiol, 313:F621-F628.

[61] Ansari A, Rahman MS, Saha SK, Saikot FK, Deep A, Kim KH (2017). Function of the SIRT3 mitochondrial deacetylase in cellular physiology, cancer, and neurodegenerative disease. Aging Cell, 16:4-16.

[62] Lorenz EC, Vrtiska TJ, Lieske JC, Dillon JJ, Stegall MD, Li X, et al. (2010). Prevalence of renal artery and kidney abnormalities by computed tomography among healthy adults. Clin J Am Soc Nephrol, 5:431-438.

[63] Takazakura E, Sawabu N, Handa A, Takada A, Shinoda A, Takeuchi J (1972). Intrarenal vascular changes with age and disease. Kidney Int, 2:224-230.

[64] Tanaka T, Kato H, Kojima I, Ohse T, Son D, Tawakami T, et al. (2006). Hypoxia and expression of hypoxia-inducible factor in the aging kidney. $\mathrm{J}$ Gerontol A Biol Sci Med Sci, 61:795-805.

[65] Jerkic M, Vojvodic S, Lopez-Novoa JM (2001). The mechanism of increased renal susceptibility to toxic substances in the elderly. Part I. The role of increased vasoconstriction. Int Urol Nephrol, 32:539-547.

[66] Hajduczok G, Chapleau MW, Abboud FM (1991). Increase in sympathetic activity with age. II. Role of impairment of cardiopulmonary baroreflexes. Am J Physiol, 260:H1121-1127.

[67] Shay JW (2018). Telomeres and aging. Curr Opin Cell Biol, 52:1-7.

[68] Bernardes de Jesus B, Vera E, Schneeberger K, Tejera AM, Ayuso E, Bosch F, et al. (2012). Telomerase gene therapy in adult and old mice delays aging and increases longevity without increasing cancer. EMBO Mol Med, 4:691-704.

[69] Harris RC, Cheng H (2016). Telomerase, autophagy and acute kidney injury. Nephron, 134:145-148.

[70] Stevens LA, Li S, Wang C, Huang C, Becker BN, Bomback AS, et al. (2010). Prevalence of CKD and comorbid illness in elderly patients in the United States: results from the Kidney Early Evaluation Program (KEEP). Am J Kidney Dis, 55:S23-33.
[71] Zhang L, Zhang P, Wang F, Zuo L, Zhou Y, Shi Y, et al. (2008). Prevalence and factors associated with CKD: a population study from Beijing. Am J Kidney Dis, 51:373-384.

[72] Arora P, Vasa P, Brenner D, Iglar K, McFarlane P, Morrison H, et al. (2013). Prevalence estimates of chronic kidney disease in Canada: results of a nationally representative survey. CMAJ, 185:E417423.

[73] Zhang QL, Rothenbacher D (2008). Prevalence of chronic kidney disease in population-based studies: systematic review. BMC Public Health, 8:117.

[74] Wen CP, Cheng TY, Tsai MK, Chang YC, Chan HT, Tsai SP, et al. (2008). All-cause mortality attributable to chronic kidney disease: a prospective cohort study based on 462293 adults in Taiwan. Lancet, 371:21732182.

[75] Tsai MH, Hsu CY, Lin MY, Yen MF, Chen HH, Chiu $\mathrm{YH}$, et al. (2018). Incidence, Prevalence, and duration of chronic kidneydDisease in Taiwan: results from a community-based screening program of 106,094 individuals. Nephron, 140:175-184.

[76] Anderson S, Halter JB, Hazzard WR, Himmelfarb J, Horne FM, Kaysen GA, et al. (2009). Prediction, progression, and outcomes of chronic kidney disease in older adults. J Am Soc Nephrol, 20:1199-1209.

[77] Kidney Disease: Improving Global Outcomes (KDIGO) CKD Work Group (2013). KDIGO 2012 Clinical Practice Guideline for the evaluation and management of chronic kidney disease. Kidney inter., Suppl., 3:1-150.

[78] Wang F, He K, Wang J, Zhao MH, Li Y, Zhang L, et al. (2018). Prevalence and risk factors for CKD: a comparison between the adult populations in China and the United States. Kidney Int Rep, 3:1135-1143.

[79] Chou YH, Huang TM, Chu TS (2017). Novel insights into acute kidney injury-chronic kidney disease continuum and the role of renin-angiotensin system. J Formos Med Assoc, 116:652-659.

[80] Chou YH, Huang TM, Pan SY, Chang CH, Lai CF, $\mathrm{Wu} \mathrm{VC}$, et al. (2017). Renin-angiotensin system inhibitor is associated with lower risk of ensuing chronic kidney disease after functional recovery from acute kidney injury. Sci Rep, 7:46518.

[81] Schmitt R, Coca S, Kanbay M, Tinetti ME, Cantley LG, Parikh CR (2008). Recovery of kidney function after acute kidney injury in the elderly: a systematic review and meta-analysis. Am J Kidney Dis, 52:262271.

[82] Obi Y, Kimura T, Nagasawa Y, Yamamoto R, Yasuda $\mathrm{K}$, Sasaki K, et al. (2010). Impact of age and overt proteinuria on outcomes of stage 3 to 5 chronic kidney disease in a referred cohort. Clin J Am Soc Nephrol, 5:1558-1565.

[83] Abbate M, Zoja C, Remuzzi G (2006). How does proteinuria cause progressive renal damage? J Am Soc Nephrol, 17:2974-2984.

[84] Farrington K, Covic A, Nistor I, Aucella F, Clyne N, De Vos L, et al. (2017). Clinical Practice Guideline on management of older patients with chronic kidney 
disease stage $3 \mathrm{~b}$ or higher $(\mathrm{eGFR}<45 \mathrm{~mL} / \mathrm{min} / 1.73$ $\mathrm{m} 2$ ): a summary document from the European Renal Best Practice Group. Nephrol Dial Transplant, 32:916.

[85] Tangri N, Grams ME, Levey AS, Coresh J, Appel LJ, Astor BC, et al. (2016). Multinational assessment of accuracy of equations for predicting risk of kidney failure: a meta-analysis. JAMA, 315:164-174.

[86] Tangri N, Stevens LA, Griffith J, Tighiouart H, Djurdjev O, Naimark D, et al. (2011). A predictive model for progression of chronic kidney disease to kidney failure. JAMA, 305:1553-1559.

[87] Ishani A, Xue JL, Himmelfarb J, Eggers PW, Kimmel PL, Molitoris BA, et al. (2009). Acute kidney injury increases risk of ESRD among elderly. J Am Soc Nephrol, 20:223-228.

[88] Parfrey PS, Foley RN (1999). The clinical epidemiology of cardiac disease in chronic renal failure. J Am Soc Nephrol, 10:1606-1615.

[89] Hallan SI, Matsushita K, Sang Y, Mahmoodi BK, Black C, Ishani A, et al. (2012). Age and association of kidney measures with mortality and end-stage renal disease. JAMA, 308:2349-2360.

[90] Brugts JJ, Knetsch AM, Mattace-Raso FU, Hofman A, Witteman JC (2005). Renal function and risk of myocardial infarction in an elderly population: the Rotterdam Study. Arch Intern Med, 165:2659-2665.

[91] O'Hare AM, Hailpern SM, Pavkov ME, Rios-Burrows N, Gupta I, Maynard C, et al. (2010). Prognostic implications of the urinary albumin to creatinine ratio in veterans of different ages with diabetes. Arch Intern Med, 170:930-936.

[92] Stevens RJ, Evans J, Oke J, Smart B, Hobbs FDR, Holloway E, et al. (2018). Kidney age, not kidney disease. Canadian Medical Association Journal, 190:E389-E393.

[93] Tonelli M, Riella MC (2014). Chronic kidney disease and the aging population. Kidney International, 85:487-491.

[94] Delanaye P, Glassock RJ, Pottel H, Rule AD (2016). An age-calibrated definition of chronic kidney disease: rationale and benefits. Clin Biochem Rev, 37:17-26.

[95] Wongrakpanich S, Wongrakpanich A, Melhado K, Rangaswami J (2018). A comprehensive review of non-steroidal anti-inflammatory drug use in the elderly. Aging Dis, 9:143-150.

[96] Kirkman MS, Briscoe VJ, Clark N, Florez H, Haas LB, Halter JB, et al. (2012). Diabetes in older adults: a consensus report. J Am Geriatr Soc, 60:2342-2356.

[97] Chapter 12. Older adults: Standards of medical care in diabetes-2019. Diabetes Care, 42:S139-S147.

[98] Chopra HK, Ram CVS (2019). Recent guidelines for hypertension. Circ Res, 124:984-986.

[99] Williams B, Mancia G, Spiering W, Agabiti Rosei E, Azizi M, Burnier M, et al. (2018). 2018 ESC/ESH Guidelines for the management of arterial hypertension. Eur Heart J, 39:3021-3104.

[100] Arnett DK, Blumenthal RS, Albert MA, Buroker AB, Goldberger ZD, Hahn EJ, et al. (2019). 2019
ACC/AHA Guideline on the Primary Prevention of Cardiovascular Disease: Executive Summary: A Report of the American College of Cardiology/American Heart Association Task Force on Clinical Practice Guidelines. Circulation, 140:e563-e595.

[101] Mach F, Baigent C, Catapano AL, Koskinas KC, Casula M, Badimon L, et al. (2020). 2019 ESC/EAS Guidelines for the management of dyslipidaemias: lipid modification to reduce cardiovascular risk. Eur Heart J, 41:111-188.

[102] Johnson KC, Whelton PK, Cushman WC, Cutler JA, Evans GW, Snyder JK, et al. (2018). Blood pressure measurement in SPRINT (Systolic Blood Pressure Intervention Trial). Hypertension, 71:848-857.

[103] (2019). American Geriatrics Society 2019 Updated AGS Beers Criteria(R) for potentially inappropriate medication use in older adults. J Am Geriatr Soc, 67:674-694.

[104] Chang CB, Lai HY, Hwang SJ, Yang SY, Wu RS, Chang LY, et al. (2019). The updated PIM-Taiwan criteria: a list of potentially inappropriate medications in older people. Ther Adv Chronic Dis, 10:2040622319879602.

[105] Anderson S, Eldadah B, Halter JB, Hazzard WR, Himmelfarb J, Horne FM, et al. (2011). Acute kidney injury in older adults. J Am Soc Nephrol, 22:28-38.

[106] Coca SG (2010). Acute kidney injury in elderly persons. Am J Kidney Dis, 56:122-131.

[107] Cushman WC, Evans GW, Byington RP, Goff DC, Jr., Grimm RH, Jr., Cutler JA, et al. (2010). Effects of intensive blood-pressure control in type 2 diabetes mellitus. N Engl J Med, 362:1575-1585.

[108] Wright JT, Jr., Williamson JD, Whelton PK, Snyder JK, Sink KM, Rocco MV, et al. (2015). A randomized trial of intensive versus standard blood-pressure control. N Engl J Med, 373:2103-2116.

[109] Turgut F, Balogun RA, Abdel-Rahman EM (2010). Renin-angiotensin-aldosterone system blockade effects on the kidney in the elderly: benefits and limitations. Clin J Am Soc Nephrol, 5:1330-1339.

[110] Chen YM, Chiang WC, Lin SL, Tsai TJ (2017). Therapeutic efficacy of pentoxifylline on proteinuria and renal progression: an update. J Biomed Sci, 24:84.

[111] Donate-Correa J, Tagua VG, Ferri C, Martin-Nunez E, Hernandez-Carballo C, Urena-Torres P, et al. (2019). Pentoxifylline for renal protection in diabetic kidney disease. a model of old drugs for new horizons. J Clin Med, 8.

[112] Barkhordari K, Karimi A, Shafiee A, Soltaninia H, Khatami MR, Abbasi K, et al. (2011). Effect of pentoxifylline on preventing acute kidney injury after cardiac surgery by measuring urinary neutrophil gelatinase - associated lipocalin. J Cardiothorac Surg, 6:8.

[113] Yang SK, Duan SB, Pan P, Xu XQ, Liu N, Xu J (2015). Preventive effect of pentoxifylline on contrastinduced acute kidney injury in hypercholesterolemic rats. Exp Ther Med, 9:384-388. 
[114] Tian J, Shen P, Pan K, Zhou Q (2019). Efficacy of pentoxifylline treatment for neonatal sepsis: a metaanalysis of randomized controlled studies. Ital J Pediatr, 45:108.

[115] Li Y, Xia T, Li R, Tse G, Liu T, Li G (2019). Renalprotective effects of the peroxisome Proliferatoractivated receptor-gamma agonist pioglitazone in ob/ob mice. Med Sci Monit, 25:1582-1589.

[116] Maquigussa E, Paterno JC, de Oliveira Pokorny GH, da Silva Perez M, Varela VA, da Silva Novaes A, et al. (2018). Klotho and PPAR gamma activation mediate the renoprotective effect of losartan in the 5/6 nephrectomy model. Front Physiol, 9:1033.

[117] Ma Y, Shi M, Wang Y, Liu J (2020). PPARgamma and its agonists in chronic kidney disease. Int $\mathrm{J}$ Nephrol, 2020:2917474.

[118] Hong W, Hu S, Zou J, Xiao J, Zhang X, Fu C, et al. (2015). Peroxisome proliferator-activated receptor $\gamma$ prevents the production of NOD-like receptor family, pyrin domain containing 3 inflammasome and interleukin $1 \beta$ in HK-2 renal tubular epithelial cells stimulated by monosodium urate crystals. Mol Med Rep, 12:6221-6226.

[119] McMurray JJV, Solomon SD, Inzucchi SE, Kober L, Kosiborod MN, Martinez FA, et al. (2019). Dapagliflozin in patients with heart failure and reduced ejection fraction. N Engl J Med, 381:19952008 .

[120] DeFronzo RA, Norton L, Abdul-Ghani M (2017). Renal, metabolic and cardiovascular considerations of SGLT2 inhibition. Nat Rev Nephrol, 13:11-26.

[121] Heerspink HJL, Karasik A, Thuresson M, MelzerCohen C, Chodick G, Khunti K, et al. (2020). Kidney outcomes associated with use of SGLT2 inhibitors in real-world clinical practice (CVD-REAL 3): a multinational observational cohort study. Lancet Diabetes Endocrinol, 8:27-35.

[122] Wanner C, Brenner S (2019). CREDENCE and DELIGHT deliver on renal benefits. Nat Rev Nephrol, 15:459-460.
[123] Hu MC, Shi M, Gillings N, Flores B, Takahashi M, Kuro OM, et al. (2017). Recombinant alpha-Klotho may be prophylactic and therapeutic for acute to chronic kidney disease progression and uremic cardiomyopathy. Kidney Int, 91:1104-1114.

[124] Zhu Y, Tchkonia T, Pirtskhalava T, Gower AC, Ding $\mathrm{H}$, Giorgadze N, et al. (2015). The Achilles' heel of senescent cells: from transcriptome to senolytic drugs. Aging Cell, 14:644-658.

[125] Chen YM, Wang YC, Hwang SJ, Lin SH, Wu KD (2016). Patterns of dialysis initiation affect outcomes of incident hemodialysis patients. Nephron, 132:3342.

[126] Cooper BA, Branley P, Bulfone L, Collins JF, Craig JC, Fraenkel MB, et al. (2010). A randomized, controlled trial of early versus late initiation of dialysis. N Engl J Med, 363:609-619.

[127] Kurella Tamura M, Desai M, Kapphahn KI, Thomas IC, Asch SM, Chertow GM (2018). Dialysis versus medical management at different ages and levels of kidney function in veterans with advanced CKD. J Am Soc Nephrol, 29:2169-2177.

[128] Brar A, Mallappallil M, Stefanov DG, Kau D, Salifu MO (2017). Dialysis in the elderly and impact of institutionalization in the United States Renal Data System. Am J Nephrol, 46:114-119.

[129] Kurella Tamura M, Covinsky KE, Chertow GM, Yaffe K, Landefeld CS, McCulloch CE (2009). Functional status of elderly adults before and after initiation of dialysis. N Engl J Med, 361:1539-1547.

[130] Alfaadhel TA, Soroka SD, Kiberd BA, Landry D, Moorhouse P, Tennankore KK (2015). Frailty and mortality in dialysis: evaluation of a clinical frailty scale. Clin J Am Soc Nephrol, 10:832-840.

[131] Rosansky SJ (2012). The sad truth about early initiation of dialysis in elderly patients. JAMA, 307:1919-1920. 